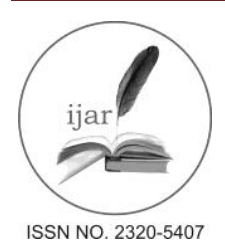

Journal homepage: http://www.journalijar.com

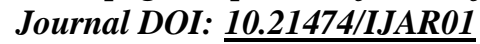

INTERNATIONAL JOURNAL'

OF ADVANCED RESEARCH

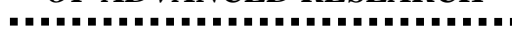

RESEARCH ARTICLE

\title{
ECONOMIC STATUS OF WOMEN LABORERS ENGAGED IN PADDY TRANSPLANTING ACTIVITY IN ALLAHABAD REGION OF UTTAR PRADESH
}

\author{
Razia Parvez ${ }^{1}$, A.K.A. Lawrance ${ }^{2}$, Swarn Lata ${ }^{3}$. \\ 1. Associate Professor/PI, Family Resource Management, Ethelind School of Home Science, SHIATS, Allahabad. \\ 2. Professor/Co-PI, SHIATS, Allahabad \\ 3. J.R.F., Family Resource Management, Ethelind School of Home Science, SHIATS, Allahabad
}

\section{Manuscript Info}

Manuscript History:

Received: 17 March 2016

Final Accepted: 26 April 2016

Published Online: May 2016

Key words:

Women Laborers, Economic,

Family Background Information

*Corresponding Author

Razia Parvez.

\begin{abstract}
Women contribute $50-60 \%$ of labour in farm production in India. There is evidence to suggest that if agriculture were focused on women, outputs could increase by as much as $10-20 \%$, the ecological balance could be restored, and food security of communities improved. India has a predominantly agrarian economy. The $70 \%$ of her population is rural; of those households, $60 \%$ engage in agriculture as their main source of income. It has always been India's most important economic sector. In this important agricultural sector woman plays a vital role, because it is largely a household enterprise Kavya Dashora (2010). The objective of the study was to study the demographic profile and economic status of women labourers engaged in paddy transplanting activity. Fifty one women labourers were selected for the study. They were aged between 20-60 years. A set of Interview schedule was design to measure their economical status of women labourers. Total 76.5 percent women labourers were illiterate, 15.7 percent women labourers were educated primary school, 1.9 percent women abourers were Junior High School and 5.9 percent women labourers were High School. 31.4 percent women abourerswere having family income falling under Rs. 3000-6000/-, 25.5 percent women labourers were having family income falling under Rs. 6000-9000/-, 21.6 percent women labourers family income was falling under Rs. 9000-12000/-, and 15.7 percent women labourers family income was falling under Rs. 12000-14000/-, a very minimul ie. 5.9 percent women labours' family income was falling under Rs. 14000-18000/-. Approximately 55 percent women abourers' main occupation was Agriculture, 21.6 percent women labourers occupation was labour and 11.8 percent women labourers main occupation was Agricultural labourers, whereas 7.8 percent women labourers occupation was Animal Husbandry and a very minimul 1.9 percent women labourers were in Service and Business. Thus the women abourers economical condition was very critical. The study has suggested that a multisectoral integrated programme for promoting agricultural activities in the rural areas according to their existing conditions, available resources and with the help of nearby institutions should be started to meet the challenge of sustainable development in the Allahabad Region of Uttar Pradesh.
\end{abstract}

Copy Right, IJAR, 2016,. All rights reserved.

\section{Introduction:-}

Farm mechanization is getting some importance due to urbanization and globalization now days. Half of the population in India is engaged in farm activities uses the muscle power to increase the productivity of agriculture. Farm mechanization helps us to make efficient use of inputs, improvement in quality of produce and safety and 
comfort of women farmers, reduction in loss of produce, drudgery of women farmers. Women are more vulnerable as compared to men in physical aspects. But they are performing the most difficult operations in agriculture and allied sectors. Majority of the women who perform the agricultural activities belong to low socio-economic group. Women contribute 50-60\% of labor in farm production in India. Women in India are major producers of food in terms of value, volume and number of hours worked. Nearly 63 percent of all economically active men were engaged in agriculture as compared to 78 per cent of women. Almost 50 percent of rural female workers were classified as agricultural laborers and $37 \%$ as cultivators. About 70 percent of farm work was performed by women. It is observed that women play a significant and crucial role in agricultural development and allied fields including, main crop production, live-stock production, horticulture, post-harvesting operations, agro/social forestry, fishing etc.; it is a fact long taken for granted but ignored since ages. In this paper an attempt has been made to study the role of women in agriculture and their economic status. Agriculture is directly tied to issues such as economic independence, decision-making abilities, society and access to education and health services and this manner has created externalities such as poverty and marginalization, and compounded issues of gender inequality. The problems of women in agriculture resemble the 'progressive set of problems' that other marginalized communities face in the general population, but in a more acute and distressing manner. These problems relate to land ownership, security of tenure, land quality issues in cases where land ownership is assured, and land management issues in terms of agriculture and the support systems it requires. Any changes in land ownership and agricultural patterns affect women far more than men (positive or negative), given the existing gender roles that women are expected to fulfill, mainly related to management of the household in their reproductive roles - fuel wood collection, fodder collection, livestock tending in general, food security needs and so on. The women perform the maximum farm operations thereby contributing a lot towards the uplifitment of the economic and social status of their families and financially, accelerating the pace of rural development (Singh 2003) Rural women have been intensively involved in agriculture and its allied fields. They perform numerous labour intensive jobs such as weeding, hoeing, grass cutting, picking, and cotton stick collections. Women's contribution to the farm sector has been ignored and inadequately understood. In our economy, very few scientific attempts have been made to examine the actual participation of female labour in crop production and other subsidiary activities at the farm level. (Vinod Sharma 2005) In spite of the major role played by women in different agricultural and allied activities, their role in the decision making is negligible. They are facing economical problem in their life and every day tolerate these mental, physical drudgery problems. In addition there are many other problems which the rural farm women are facing such as, difficulties in carrying major agricultural operations, unhygienic condition in the field, time management between farm and household activities. Therefore a study was design with the objectives to demographic profile and economic status of farm women laborers engaged in paddy transplanting activity.

\section{Materials and Methods:-}

The present study entitled, "Economic Status of Women labourers Engaged in Paddy Transplanting Activity in Allahabad Region of Uttar Pradesh" was undertaken to study the economic status of women labourers. Total 51 Women labourers were selected from three main Blocks, namely Chaka (Trans Yamuna), Bahadurpur (Trans Ganga) and Kaudhihar Blocks (Kanpur Road) were selected. The villages "Baswar", "Dadri", "Maduka" and "Murlicot", were selected from Chaka Block, "Buduruddin", "Lodva" and "Yarnva" from Bahadurpur block and "Ahiran ka Pura", "Lalbihar" and "Umari" from Kaudhihar Block were selected. A presented interview schedule which includes open ended and close ended questions was used to collect the data regarding their demographic profile as well as their economic status. Questions were arranged in sections as per the objectives of the study. The women labourers shared their problems related economical status during paddy transplanting activity. Frequency percentage was used for the data interpretation.

\section{Results and Discussion:-}

The results of the present study in accordance with the objectives have been derived by the use of required methodology. Following are the main heads under which the study has been discussed.

Information Regarding Selected Blocks:-

Table presented below shows the blocks selected for the survey. 


\section{Caste}

Table: 1- Distribution of women laborers according to their caste

\section{Caste Category}

The table presented below shows the distribution of women laborers according to their caste.

\begin{tabular}{|c|c|c|c|c|c|c|c|c|}
\hline \multirow{4}{*}{$\begin{array}{r}\text { Caste } \\
\text { Category }\end{array}$} & \multicolumn{8}{|c|}{ Women Laborers } \\
\hline & \multirow{2}{*}{\multicolumn{2}{|c|}{$\begin{array}{c}\begin{array}{c}\text { Chaka Block } \\
\text { (Trans Yamuna) }\end{array} \\
\mathbf{N}=\mathbf{1 8}\end{array}$}} & \multirow{2}{*}{\multicolumn{2}{|c|}{$\begin{array}{c}\begin{array}{c}\text { Bahadurpur } \\
\text { (Trans Ganga) }\end{array} \\
\mathbf{N}=17\end{array}$}} & \multirow{2}{*}{\multicolumn{2}{|c|}{$\begin{array}{c}\begin{array}{c}\text { Kaudhihar } \\
\text { (Kanpur Road) }\end{array} \\
\mathbf{N}=\mathbf{1 6}\end{array}$}} & \multicolumn{2}{|c|}{ Total $\mathbf{N}=51$} \\
\hline & & & & & & & & \\
\hline & $\mathrm{F}$ & $\%$ & $\mathrm{~F}$ & $\%$ & $\mathrm{~F}$ & $\%$ & $\mathrm{~F}$ & $\%$ \\
\hline $\mathrm{SC}$ & 5 & 9.8 & 13 & 25.5 & 6 & 11.8 & 24 & 47.06 \\
\hline ST & 2 & 3.9 & - & - & - & - & 2 & 3.9 \\
\hline OBC & 11 & 21.6 & 4 & 7.8 & 10 & 19.6 & 25 & 49.01 \\
\hline
\end{tabular}

The data presented in table 1 shows that in Chaka Block, the majority 21.6 percent women laborers belonged to OBC category, 9.8 percent laborers belonged to SC category whereas 3.9 percent women laborers belonged to ST caste category. In Bahadurpur Block, the majority 25.5 percent women laborers belonged to SC category and 7.8 percent women laborers belonged to OBC caste category. In Kaudhihar block, the majority 19.6 percent women laborers belonged to $\mathrm{OBC}$ category and minimum of 11.8 percent women laborers belonged to SC category respectively.

Table: 2- Distribution of women laborer according to their background information

The table presented below shows the distribution of women laborers according to their education, Age group, family size and family type.

\begin{tabular}{|c|c|c|c|c|c|c|c|c|c|}
\hline \multirow{3}{*}{\multicolumn{2}{|c|}{ Variables }} & \multicolumn{8}{|c|}{ Women Laborers } \\
\hline & & \multirow{2}{*}{\multicolumn{2}{|c|}{$\begin{array}{l}\begin{array}{l}\text { Chaka Block } \\
\text { (Trans Yamuna) }\end{array} \\
\text { N=18 }\end{array}$}} & \multirow{2}{*}{\multicolumn{2}{|c|}{$\begin{array}{l}\begin{array}{l}\text { Bahadurpur } \\
\text { (Trans Ganga) }\end{array} \\
\mathbf{N}=17\end{array}$}} & \multicolumn{2}{|c|}{$\begin{array}{l}\text { Kaudhihar } \\
\text { (Kanpur Road) }\end{array}$} & \multicolumn{2}{|c|}{ Total $\mathbf{N}=51$} \\
\hline & & & & & & & $N=16$ & & \\
\hline \multicolumn{2}{|c|}{ Education } & $\mathrm{F}$ & $\%$ & $\mathrm{~F}$ & $\%$ & $\mathrm{~F}$ & $\%$ & $\mathrm{~F}$ & $\%$ \\
\hline \multicolumn{2}{|c|}{ Illiterate } & 14 & 27.5 & 13 & 25.5 & 12 & 23.5 & 39 & 76.5 \\
\hline \multicolumn{2}{|l|}{ Primary } & 1 & 1.9 & 3 & 5.9 & 4 & 7.8 & 8 & 15.7 \\
\hline \multicolumn{2}{|l|}{ 8th class } & 1 & 1.9 & - & - & - & - & 1 & 1.9 \\
\hline \multicolumn{2}{|c|}{ High school } & 2 & 2.9 & 1 & 1.9 & - & - & 3 & 5.9 \\
\hline \multicolumn{10}{|c|}{ Age ( in year) } \\
\hline \multicolumn{2}{|c|}{$20-25$} & 1 & 1.9 & 2 & 3.9 & 3 & 5.9 & 6 & 11.8 \\
\hline \multicolumn{2}{|l|}{$25-30$} & 5 & 9.8 & 1 & 1.9 & - & & 6 & 11.8 \\
\hline \multicolumn{2}{|l|}{$30-35$} & 3 & 5.9 & 5 & 9.8 & 9 & 17.6 & 17 & 33.3 \\
\hline \multicolumn{2}{|l|}{$35-40$} & 6 & 11.8 & 5 & 9.8 & 4 & 7.8 & 15 & 29.4 \\
\hline \multicolumn{2}{|l|}{$40-45$} & 1 & 1.9 & 3 & 5.9 & - & & 3 & 5.9 \\
\hline \multicolumn{2}{|l|}{$45-50$} & 1 & 1.9 & 1 & 1.9 & - & & 2 & 2.9 \\
\hline \multicolumn{2}{|l|}{$50-60$} & 1 & 1.9 & - & & - & & 1 & 1.9 \\
\hline \multirow{2}{*}{$\begin{array}{l}\text { Family } \\
\text { Size }\end{array}$} & $\begin{array}{l}\text { Members } \\
1-5 \\
\text { Small }\end{array}$ & 9 & 17.6 & 11 & 21.6 & 10 & 19.6 & 30 & 58.8 \\
\hline & $\begin{array}{l}\text { Medium } \\
6-8 \\
\text { members }\end{array}$ & 9 & 17.6 & 6 & 11.8 & 6 & 11.8 & 21 & 41.2 \\
\hline $\begin{array}{l}\text { Family } \\
\text { Type }\end{array}$ & Nuclear & 18 & 35.3 & 17 & 33.3 & 16 & 31.4 & 51 & 100 \\
\hline
\end{tabular}

\section{Education}

The data presented in table 2 reveals that the women laborers of Chaka Block, the majority 27.5 percent women laborers were illiterate, 2.9 percent women laborers were high school whereas 1.9 percent women laborers were educated only up to primary and junior high school. The farm women of Bahadurpur Block, the majority 25.5 percent women laborers were illiterate whereas 5.9 percent women laborers were educated up to primary level and very minimum ie. 1.9 percent women laborers were educated up to high school only. The farm women of Kaudhihar 
Block, the majority 23.5 percent farm women were illiterate and only 7.8 percent farm women were educated up to primary level. Not even a single woman was intermediate and graduate.

Age

In Chaka Block, the 9.8 percent women laborers were falling under the age group of 25-30 years whereas 5.9 percent women laborers were falling under the age group of 30-35 years and very minimum ie. 1.9 percent women laborers were falling under the age group of 20-25, 40-45, 45-50 and 50.60 years respectively. The farm women of Bahadurpur Block, the majority 9.8 percent farm women were falling under the age group of 30-35 years, 35-40 years and 5.9 percent farm women were falling under the age group of 40-45 years and very minimum ie. 1.9 percent farm women were falling under the age group of 45-50 years. The farm women of Kaudhihar Block, the majority 11.8 percent farm women were falling under the age group of 40-45 years and 5.9 percent farm women were falling under the age group of 20-25 years, 25-30 and 45-50 years and 1.9 percent farm women were falling under the age group of 40-45 years.

\section{Family Size}

Almost 50 percent of women labourers in tree blocks were having small (1-5 members) and medium (6-8 members) family size.

Family Type

All the women labourers of three blocks were having nuclear family only. Not even a single family was having joint family.

Table 3:- Distribution of women laborers according to their husband occupation

\begin{tabular}{|c|c|c|c|c|c|c|c|c|}
\hline \multirow{4}{*}{$\begin{array}{l}\text { Husband } \\
\text { Occupation }\end{array}$} & \multicolumn{8}{|c|}{ Women Laborers } \\
\hline & \multirow{2}{*}{\multicolumn{2}{|c|}{$\begin{array}{l}\text { Chaka Block } \\
\text { (Trans Yamuna) } \\
\text { N=18 }\end{array}$}} & \multirow{2}{*}{\multicolumn{2}{|c|}{$\begin{array}{l}\begin{array}{l}\text { Bahadurpur } \\
\text { (Trans Ganga) }\end{array} \\
\text { N=17 }\end{array}$}} & \multirow{2}{*}{\multicolumn{2}{|c|}{$\begin{aligned} \begin{array}{l}\text { Kaudhihar } \\
\text { (Kanpur Road) }\end{array} & \text { N=16 }\end{aligned}$}} & \multicolumn{2}{|c|}{ Total $\mathbf{N}=51$} \\
\hline & & & & & & & & \\
\hline & $\mathrm{F}$ & $\%$ & $\mathrm{~F}$ & $\%$ & $\mathrm{~F}$ & $\%$ & $\mathrm{~F}$ & $\%$ \\
\hline Business & 2 & 3.9 & 2 & 3.9 & 5 & 9.8 & 9 & 17.6 \\
\hline Wage labor & 4 & 7.8 & 4 & 7.8 & 4 & 7.8 & 12 & 23.6 \\
\hline Farming & 10 & 19.6 & 8 & 15.7 & 4 & 7.8 & 22 & 43.2 \\
\hline Gov. Service & - & - & 1 & 1.9 & - & - & 1 & 1.9 \\
\hline Private Service & 2 & 3.9 & 2 & 3.9 & 3 & 5.9 & 7 & 13.7 \\
\hline
\end{tabular}

The data presented in table 4 reveals that the in Chaka Block the majority 19.6 percent women laborers husband occupation were farming, 7.8 percent women laborers husband's occupation were wage labor 3.9 percent women laborers husband's occupation were business and as well as private service. In Bhadurpur Block 15.7 percent women laborers husband's occupation was farming and 7.8 percent women laborers husband's occupation was wage labor whereas very minimum 1.9 percent woman laborers husband occupation was government service. In Kaudihar Block 9.8 percent women laborers husband's occupation were business 7.8 percent women laborers husband's occupation was wage labor and farming and 5.9 percent women laborers husband's occupation was private service.

\section{Mode of Payment}

Graph 2 - Distribution of women laborers according to their mode of payment. 


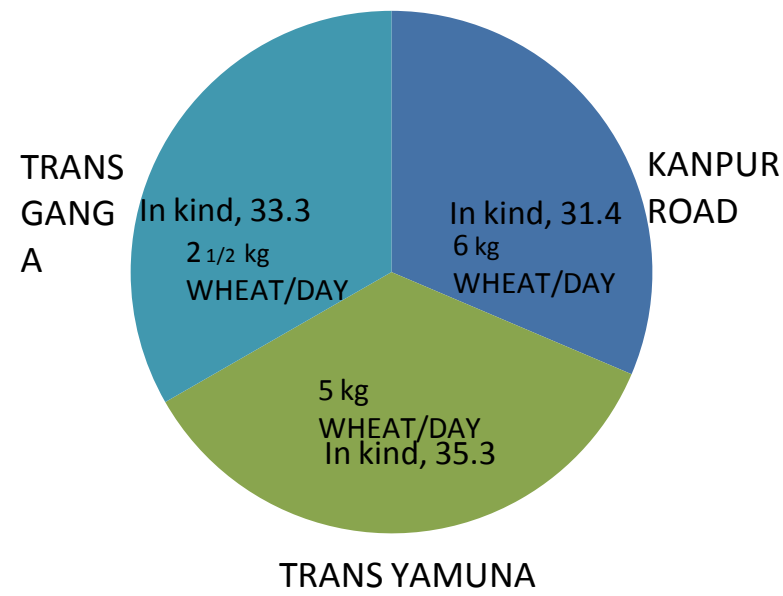

The data presented in graph 2 revels that from selected each three blocks the out of total majority 35.3 percent women laborers were getting in kind $5 \mathrm{~kg}$ wheat per day in Chaka Block, in Bhadurpur Block 33.3 percent women laborers were getting $2 \frac{1}{2} \mathrm{~kg}$ wheat per day and in Kaudhihar Block 31.4 percent women laborers were also getting in kind $6 \mathrm{~kg}$ wheat per day.

\section{Monthly Family Income}

The table presented below shows the distribution of women laborers according to their monthly family income.

Table: 4- Distribution of women laborers according to their monthly family income

\begin{tabular}{|c|c|c|c|c|c|c|c|c|}
\hline \multirow{4}{*}{$\begin{array}{l}\text { Monthly } \\
\text { Family } \\
\text { Income from } \\
\text { all the sources }\end{array}$} & \multicolumn{8}{|c|}{ Women Laborers } \\
\hline & \multirow{2}{*}{\multicolumn{2}{|c|}{$\begin{array}{c}\begin{array}{l}\text { Chaka Block } \\
\text { (Trans Yamuna) }\end{array} \\
\mathrm{N}=18\end{array}$}} & \multirow{2}{*}{\multicolumn{2}{|c|}{$\begin{array}{c}\begin{array}{l}\text { Bahadurpur } \\
\text { (Trans Ganga) }\end{array} \\
\mathbf{N}=16\end{array}$}} & \multirow{2}{*}{\multicolumn{2}{|c|}{$\begin{array}{c}\begin{array}{c}\text { Kaudhihar } \\
\text { (Kanpur Road) }\end{array} \\
\mathrm{N}=16\end{array}$}} & \multicolumn{2}{|c|}{ Total $\mathbf{N}=51$} \\
\hline & & & & & & & & \\
\hline & $\mathrm{F}$ & $\%$ & $\mathrm{~F}$ & $\%$ & $\mathrm{~F}$ & $\%$ & $\mathrm{~F}$ & $\%$ \\
\hline $3000-6000$ & 3 & 5.9 & 8 & 15.7 & 5 & 9.8 & 16 & 31.4 \\
\hline $6000-9000$ & 4 & 7.8 & 3 & 5.9 & 7 & 13.7 & 14 & 25.5 \\
\hline $9000-12000$ & 6 & 11.8 & 4 & 7.8 & 1 & 1.9 & 11 & 21.6 \\
\hline $12000-14000$ & 2 & 3.9 & 2 & 3.9 & 3 & 5.9 & 8 & 15.7 \\
\hline $14000-18000$ & 3 & 5.9 & - & - & - & & 3 & 5.9 \\
\hline
\end{tabular}

The data presented in table 4 revels that the in Chaka Block the majority of respondent 11.8 percent had their monthly family income under Rs. 9000-12000 from all sources, 7.8 percent women laborers had their monthly family income under Rs. 6000-9000 from all sources and 5.9 percent women laborers had their monthly family income under Rs. 3000-6000 as well as Rs.14000-18000 from all source whereas very minimum 3.9 percent women laborers had their monthly family income under Rs. 12000-14000 from all sources.

In Kaudihar Block the majority of respondent 13.7 percent women laborers had their monthly family income under Rs. 6000-9000 from all sources, 9.8 percent women laborers had their monthly family income under Rs. 3000-6000 from all sources and very minimum 3.9 percent women laborers had their monthly family income under Rs. 12000-14000 from all sources.

In Bahadurpur Block, 13.7 percent women laborers had their monthly family income under Rs. 6000-9000 from all sources and 9.8 percent women laborers had their monthly family income under Rs. 3000-6000 from all sources whereas very minimum 1.9 percent women laborers had their monthly family income under Rs. 9000-12000 from all sources

The marginal and small holdings, even if having a high productivity levels, are not able to generate sufficient income to sustain the farm households. The Situation Assessment Survey of Farmers (NSS, 2003) has found that farm households, on an average, were in deficit, the average monthly expenditure being Rs. 2770 and average income from all sources being Rs. 2115. The net income from all sources of a marginal farmer was Rs. 1659/month and of a small farmer was Rs. 2453/month. 


\section{Land Holding Categories}

The graph presented below shows the distribution of women laborers according to their land holding categories.

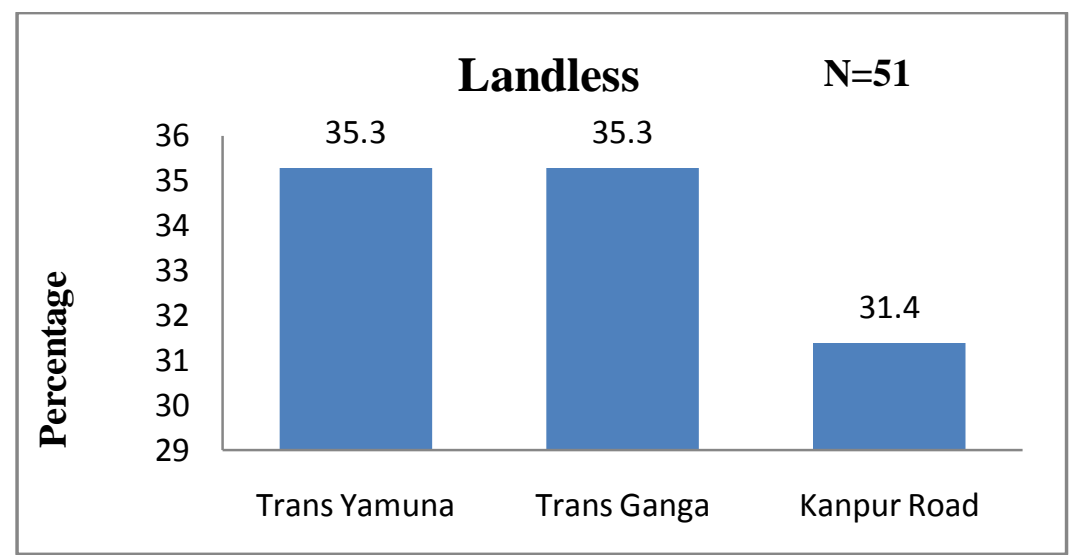

\section{Graph 3- Distribution of women laborers according to their landholding categories}

The above graph 3 indicates that the cent-percent women laborers was not having their own land for farming as they were landless in the above selected blocks during paddy transplanting activities. (Note: paddy transplanting is very costly for farming)

In 2004-05, the poverty ratio for all farmers was estimated to be 15.2 per cent, with 22.0 per cent among landless farmers, 20.0 per cent among sub marginal farmers, 18.1 per cent among marginal farmers, 14.8 per cent among small farmers and 9.8per cent among medium and large farmers (Chadha, 2008).

\section{Main Occupation}

The table presented below shows the distribution of women laborers according to their Main Occupation.

Table 5: Distribution of families of women laborers according to their main occupation

\begin{tabular}{|c|c|c|c|c|c|c|c|c|}
\hline \multirow{4}{*}{$\begin{array}{l}\text { Main } \\
\text { Occupation }\end{array}$} & \multicolumn{8}{|c|}{ Women Laborers } \\
\hline & \multirow{2}{*}{\multicolumn{2}{|c|}{$\begin{array}{c}\text { Chaka Block } \\
\mathrm{N}=18\end{array}$}} & \multirow{2}{*}{\multicolumn{2}{|c|}{$\begin{array}{c}\text { Bahadurpur } \\
\mathrm{N}=17\end{array}$}} & \multirow{2}{*}{\multicolumn{2}{|c|}{$\begin{array}{c}\text { Kaudhihar } \\
\mathrm{N}=16\end{array}$}} & \multicolumn{2}{|c|}{ Total N=51 } \\
\hline & & & & & & & & \\
\hline & $\mathbf{F}$ & $\%$ & $\mathbf{F}$ & $\%$ & $\mathbf{F}$ & $\%$ & $\mathbf{F}$ & $\%$ \\
\hline $\begin{array}{l}\text { Agriculture } \\
\text { Labour }\end{array}$ & 11 & 21.6 & 9 & 17.6 & 12 & 23.5 & 32 & 62.8 \\
\hline Business & - & - & - & - & 2 & 3.9 & 2 & 3.9 \\
\hline Service & - & - & 2 & 3.9 & - & & 2 & 3.9 \\
\hline Wage & 7 & 13.7 & 4 & 7.8 & - & & 11 & 21.6 \\
\hline $\begin{array}{l}\text { Animal } \\
\text { husbandry }\end{array}$ & - & - & 2 & 3.9 & 2 & 3.9 & 4 & 7.8 \\
\hline
\end{tabular}

The data presented in Table 5 reveals that in Chaka Block 19.6 percent women laborer family's main occupation was agriculture, whereas 13.7 percent women laborers main occupation was labor and very minimum 1.9 percent women laborers main occupation was Agriculture laborers.

In Bahadurpur Block the majority of 13.7 percent women laborers main occupation was Agriculture whereas 7.8 percent women laborers main occupation was labor and very minimum 1.9 percent women laborers main occupation was service.

In Kaudhihar Block the majority of 21.5percent women laborers main occupation was Agriculture whereas 3.9percent women laborers main occupation was Agriculture Laborers and Animal husbandry and very minimum 1.9 percent women laborers main occupation was business.

A Similar study was done According to population census of India 2001, there are about 402.5 million rural workers of which 127.6 million are cultivators and 107.5 million are agricultural laborers. In other words, pure agricultural workers constitute nearly 58.4 per cent of the total rural workers, of which 31.7 percent are owner cultivators and 
26.7 percent are mainly agricultural wage earners (Agriculture Statistics at a Glance, sourced from Registrar General of India, New Delhi 2001.

A Similar study was done According to population census of India 2001, there are about 402.5 million rural workers of which 127.6 million are cultivators and 107.5 million are agricultural laborers. In other words, pure agricultural workers constitute nearly 58.4 per cent of the total rural workers, of which 31.7 percent are owner cultivators and 26.7 percent are mainly agricultural wage earners (Agriculture Statistics at a Glance, sourced from Registrar General of India, New Delhi 2001).

\section{Conclusion:-}

The women labourers were suffering from economical problem, mostly were illiterate they not aware about any government policies and working in farm for their survival of life. Therefore the women laborers economical condition was very critical. They need to be aware of all related farm techniques and policies of Government related to farming. The study has suggested that a multi- sectoral integrated programme for promoting agricultural activities in the rural areas according to their existing conditions, available resources and with the help of nearby institutions should be started to meet the challenge of sustainable development in the Allahabad Region of Uttar Pradesh.

\section{Reference:-}

1. Ajit Kumar Singh, (2013). "Income And Livelihood Issues Of Farmers: A Field Study In Uttar Pradesh" Agricultural Economics Research Review Vol. 26 (Conference Number) 2013 pp 89-96.

2. Chadha, G.K., (2008). Employment and Poverty in Rural India: Which way to go now, ILO Asia Pacific Working Paper Series, 2008.

3. E. Krishna Rao; (2006). Research Centre for Social Sciences, Mumbai, India in its journal Economy. Volume 2; Issue (Month): 2 (June)Pages: 107-118

4. Hemla Aggarwal, Subita Sharma and Rajni Sharma (2013). "A Study of Agricultural Activities Performed by Rural Women and Problems Faced by them in Jammu District of J\&K State", International Journal of Scientific and Research Publications, Volume 3, Issue 1, ISSN 2250-3153.

5. Singh, Seema; ( 2003). "Kurukshetra”, Monthly Journal of Rural Development, Volume 59, No 11, pp. 6-7.

6. Grover, G; (2004). Women in Agriculture Development Agrotech Publishing Academy, Udaipur.Infochangeindia.org/agenda/.../women-farmers-

7. Gupta, M.P 2005: Empowerment of women in Agriculture. Daily Excelsior, 28 May 2006.

8. Kar S.K., Dhara PC (2007). An evaluation of musculoskeletal disorder and socio-economic status of farmers in West Bengal, India. Nepal Medical College Journal, 9(4): 245-249. 